\title{
Effect of Different Compost as Pond Manure on the Water Quality and Growth of Labeo rohita (ham.)
}

\author{
Kamla Shankar Shukla, C.M. Tripathi and Aditya Kumar Singh* \\ Krishi Vigyan Kendra, Ganiwan, Chitrakoot, UP, India \\ *Corresponding author
}

\section{A B S T R A C T}

\section{Keywords \\ Cattle dung, Vermi compost, Pit compost, Water quality, Weight gain \\ Article Info \\ Accepted: \\ 10 January 2019 \\ Available Online: \\ 10 February 2019}

\begin{abstract}
The present study was conducted at Krishi Vigyan Kendra, Chitrakoot in earthen pond having the area of 0.017 to 0.041 ha for 120 days to study the effect of different organic manure on water quality and growth performance Labeo rohita. The compost comprises as vermicompost, Pit compost and raw cattle dung that is compared with control having no manure application. All the compost was used at fixed dose @ $5000 \mathrm{Kg} / \mathrm{ha}$ in $24 \mathrm{split}$ doses at 15 days interval and $5000 \mathrm{~kg} / \mathrm{ha}$ compost applied at 15 days prior to stocking of fish seed for pond preparation. No feed was given to fishes as supplementary feed during the study period. The physio - chemical parameters were studied at monthly basis. The parameter increased significantly in the pond over control. The maximum weight gain of rohu was obtained in vermicompost treated pond that is $90.15 \mathrm{gm}$ with highest survival of fishes (83.4\%), $44.2 \mathrm{gm}$ in raw cattle dung treated pond with $68.97 \%$ survival and 63.13 survival with $34.35 \mathrm{gm}$ individual weight in pit compost treated pond.
\end{abstract}

\section{Introduction}

Aquaculture is the fastest growing food production sector in the world with annual growth in excess of 10 percent over the last two decades. Much of this development has occurred in Asia, which also has the greatest variety of cultured species and systems.

Organic fertilizers are used to enhance the productivity of inland aquatic resources. These fertilizers directly influence the water quality parameters which is liable to form the aquatic environment. Vermi compost is a new and valuable introduction to the list of organic fertilizers used in aquaculture production. A sustainable technology is required to get higher production from existing agricultural resources. For long sustainability of the production potential there is a need to utilize all available resources and production system within each and every system. Utilization of byproduct of one farming system to another farming system is a need of today. Not only for sustainable farming but also to keep environment clean in which we are habituating. If we are unable to use these by products, that putrefy our local environment with bad odor, pollute air with the production of noxious gases. The byproduct of farming system when accumulated in open air it produces several hazards to the human beings like, Malaria, Asthmas, dengue and polluted drinking water. Disposal of Agri by products 
through proper manner without burning and recycled them to earn more benefit without polluting the environment.

Cost minimization and effective management of farm waste through different farming system helps to increase farmer's income and profitability. Increasing cost of highly proteinaceous fish production inputs likefeed, manures and fertilizers creating an interest of farming community for utilization of animal waste in aquaculture. So many aquaculture production systems are in practice like- Intensive, Semi intensive and traditional system using different level of input use. These Manures are either directly used by fishes or through production of Phyto and Zoo plank tonic communities. The vast availability of crop, live stock, poultry and pigs waste products may play a vital role in improving the livelihood of rural community with minimizing the pollution and maximizing the production. The live stock waste including animal manure, poultry by products and agriculture Waste contains variety of plants rich in protein, lipid, carbohydrates and many trace minerals and vitamins which play crucial role in production enhancement in aquaculture system. It is also necessary to manage water quality of ponds loaded with Organic manure. The nutrient and over loading of manure produces much stress to aquatic life when the water quality get putrefied. Tolerance in relation to the fishes possess through a limit of water quality. The water quality parameter when disturbed then it causes aquatic life and even they lose their equilibrium and ultimately they die. So, we must be conscious about their alteration and keep eye to manage regularly.

Main objective of the study is to assess the effect of Organic manure on the growth of Labeo rohita and water quality parameters of fish pond
To study the Growth performance of Labeo rohita in different organic manure loaded pond.

To study the suitability of water quality of pond loaded with organic manure for fish farming

To study the judicious recycling of organic wastes for the production of high quality protein at low cost.

To analyze the water quality of aquaculture pond receives organic manures.

\section{Materials and Methods}

The fish farming unit of Krishi Vigyan Kendra, Chitrakoot, was selected for the study of the Effect of different compost as pond manure on the water quality and growth of Labeo rohita (ham.). The site is located at $132.98 \mathrm{~km}$ above mean sea level of $80^{\circ} 40^{\prime}$ and $81^{\circ} 84^{\prime}$ longitude and $24^{\circ} 52^{\prime}$ and $25^{\circ}$ 25 '.latitude. The selected ponds are situated at a single place and embankment is connected to each other. The experiment was carried out pond measuring 133 Square meters to 326 square meter area for 125 days. The 4 ponds were selected for the experiment and divided as Controlled (P-1), Vermi compost (P-2), pit compost (P-3), Raw dung (P-4). The pond was dewatered and sanitized with $200 \mathrm{~kg} / \mathrm{ha}$ lime powder. After 4 days interval it was filled with tube well water up to the 1.25 meter height. The pond was get prepared with selected manure at $5000 \mathrm{~kg} / \mathrm{ha}$ and rest $5000 \mathrm{~kg} / \mathrm{ha}$ was applied after stocking at 15 days interval in 24 split doses. The pond was stocked with Indian major carp Labeo rohita fingerling@8000/ha. The average weight of fish seed was 3.00 gram/individual. The area of pond is not same for all treatment it was distributed as P-1 (326 Sqm), P-2 (217 Sqm), P-3 (133 Sqm), P-4 (177 Sqm). No supplementary feed was given to the fishes 
stocked in the pond they are depending upon natural feeds. The growth and physicochemical parameter was analyzed at monthly interval. Fish growth was measured by body length and weight gain monthly interval.

Weight gain= Body wt at the time of sampling - Initial body weight

Growth increment $=$ Total weight gain $/$ culture period

\section{Sample collection method}

The water sample was collected from all the study ponds from $50 \mathrm{~cm}$ depth at 1: $00 \mathrm{pm}$. The analysis of the water quality and growth parameters completed in between 25th Sept. to 25th Jan, 2018. The water quality parameters analyzed by standard methods in Laboratory and sample for D.O. was fixed at pond site to be taken for analysis. The water sample collected from the pond was stored in polythene containers of 5 liter capacity. $\mathrm{pH}$ and TDS estimation completed immediately after collection of sample. The Temperature and Transparency recorded in situ by Thermometer and Sacchi disc.

\section{Methods of analysis}

\begin{tabular}{|l|l|}
\hline Parameter & Method \\
\hline pH & As per standard \\
methods & of \\
Tranceparency & wamination of and waste \\
\hline Electrical conductivity & water \\
\hline Disolved Oxygen & \\
\hline Hardness & Average weight \\
\hline Total Alkalinity & \\
\hline Gm)Growth & \\
\hline
\end{tabular}

\section{Results and Discussion}

Physico-chemical and biological factor of pond water play a significant role in the biology, physiology and growth of the aquatic ecosystem. So, an aquatic ecosystem, changes in water characteristics that improve or reduce the water quality would respectively enhance or reduce the production of an aquatic crop (Diana and Lin. 1998). In the present study the water quality parameters of manure receiving pond remained within the favorable range required for Fish farming. Water temperature has prominent effect on growth rate, feed consumption and other metabolic functions of the organisms. Osborne and Riddle (1999) observed that fish growth parameters in terms of weight gain, feeding rate and feeding efficiency of grass carp showed an increasing trend with the increase in water temperature. As the sun shines over the surface of water, it starts absorbing heat and water becomes warm; the latter condition directly influences the physiological and metabolic activities of fish i.e., swimming, breathing, growth and reproduction (Jhingaran, 1982). This study water temperature ranges in between $15-28{ }^{0} \mathrm{C}$

All the metabolic and physiological activities and life processes of aquatic organism are greatly influenced by water temperature. The water temperature of the pond ranges between $15^{\circ} \mathrm{C}-28^{0} \mathrm{C}$ that was in the suitable range except minimum temperature. The Indian major carps thrive well in the temperature range of $18.3^{\circ} \mathrm{C}-37.8^{0} \mathrm{C}$ (Jhingaran, 1991).

Transparency of the study P-1 pond was ranging between 19.5-75 $\mathrm{cm}$. Whereas light penetration of P-2, P-3, P-4 pond was in between 42.58 to $58.65,38-70$ and $36.5-90.1$ $\mathrm{Cm}$ respectively this is congenial in range. The transparency of treatment pond is higher because low plank tonic organisms. In integrated fish farming organic pollutants released into the pond would minimize the light penetration and D.O. (Salt et al., 1995). The use of organic manure in fish farming is based on the assumption that the manure is utilized through two pathways. The manure organic matter provides dissolved and 
particulate substrates for bacteria and the bacterial laden particles provide food to the filter-feeding and detritus-consuming animals, while the mineralized fraction of the manure stimulates phytoplankton productivity similar to the action of inorganic fertilizers. The manure organic matter coated with bacteria is considered a link in the food web and should be treated as a food (Hepher and Pruginin, 1981).

In intensively manured fish ponds, both autotrophic and heterotrophic production contribute to fish growth (Schroeder, 1978, 1980), Fish health and production are associated with the pond environment. The temperature, $\mathrm{pH}$, dissolved oxygen and free ammonia may have a direct adverse effect on fish condition and growth, determining the upper limit of the nutrient load into the fish ponds.

The $\mathrm{pH}$ of all pond ranges between 7.7 to 8.6. Minimum $\mathrm{pH}$ was observed in control pond and maximum $\mathrm{pH}$ was recorded in raw cattle dung treated pond. The $\mathrm{pH}$ is favorable in range. Each aquatic organism has its maximum and minimum toleration range of $\mathrm{pH}$. The $\mathrm{pH}$ of most natural waters ranges between 5 and 10 (Boyd, 1990).

Bhatnagar and Devi (2013) enlisted the acceptable ranges of water quality parameters according to these researchers, the favorable ranges of different water parameters are: 3-5 $\mathrm{mg} \mathrm{L}^{-1}$ Dissolved Oxygen (DO), 7-9.5 pH, 50-200 $\mathrm{mg} \mathrm{L}^{-1}$ alkalinity, $75-150 \mathrm{mg} \mathrm{L}^{-1}$ hardness, $15-35^{\circ} \mathrm{C}$ temperature, $30-80 \mathrm{~cm}$ turbidity.

The dissolved oxygen of control pond is minimum i.e. 2.83 , it is probably due to low phyto planktonic population. The D.O. of the all treated pond was in the favorable range for survival to the fishes. The mean D.O. of treated pond ranges between $8.56-8.695 \mathrm{mg} / \mathrm{l}$.
The total hardness of control pond was ranges between 144 to $187 \mathrm{mg} / \mathrm{l}$ with mean value to $167.7 \mathrm{mg} / \mathrm{l}$. whereas in experimental pond it was ranges between 126-172.67 mg/l. In the vermicompost treated pond hardness was recorded higher than all ponds.

The Total alkalinity of all the pond ranges in between 304 to $584 \mathrm{mg} / \mathrm{l}$. The highest value observed in control pond with mean value of 485.2 and minimum was recorded in raw cattle dung treated pond. The higher alkalinity is probable due to natural and rock characteristics of the soil. Kaur and Ansal (2010) also reported significantly higher alkalinity in the water treated with vermicompost as compared to other organic manure (cow dung). Natural water bodies in tropical areas exhibit a wide range of fluctuation in total alkalinity which depends on the population of primary and secondary producers, seasons, location and nature of bottom soil Mandal (1976). However, for a higher production of planktons, alkalinity must be in the favorable range.

The alkalinity was not in range for proper growth of fishes. The electrical conductivity is ranging in between 0.818 and 0.726 which is congenial in range.

Organic manuring is widely practiced in carp production systems to ensure sustained supply of essential nutrient for augmenting natural pond productivity to obtain increased fish production at cheaper rates (Edwards, 1980). The growth of Labeo rohita in control pond was 22.25 gram in 123 day culture period with the daily weight gain of 0.182 gram. The highest weight of 90.15 gram was observed in vermicompost (P-2) treated pond with an average increase of 0.733 gram/day. Whereas raw cattle dung treated pond gives 44.20 gram average weight of fish which is higher than pit compost treated pond without inorganic fertilizers and supplementary feed. 
Table.1 Details of trials

\begin{tabular}{|l|l|}
\hline Details of ponc & Treatment \\
\hline P-1 & Control (Without manure $)$ \\
\hline P-2 & Vermi compost $(5000 \mathrm{~kg} / \mathrm{ha})$ \\
\hline $\mathbf{P - 3}$ & Pit compost $(5000 \mathrm{~kg} / \mathrm{ha})$ \\
\hline $\mathbf{P - 4}$ & Raw cattle dung $(5000 \mathrm{~kg} / \mathrm{ha})$ \\
\hline
\end{tabular}

Table.2 Physico chemical parameter of study pond

\begin{tabular}{|c|c|c|c|c|c|c|c|}
\hline Trial & Water temp ${ }^{\circ} \mathrm{C}$ & $\begin{array}{l}\text { Transparency } \\
(\mathrm{Cm})\end{array}$ & $\begin{array}{l}\text { Dissolved } \\
\text { oxygen } \\
(\mathrm{Mg} / \mathrm{l})\end{array}$ & $\begin{array}{l}\text { Hardness } \\
\mathrm{Mg} / \mathrm{l}\end{array}$ & $\begin{array}{l}\text { Total } \\
\text { alkalinity } \\
(\mathrm{Mg} / \mathrm{l})\end{array}$ & Ph & $\begin{array}{l}\text { Electrical } \\
\text { conductivity } \\
\text { ds/cm }\end{array}$ \\
\hline P-1 & $\begin{array}{l}17-27 \\
(21.75)\end{array}$ & $\begin{array}{l}19.5-75 \\
63.33\end{array}$ & $\begin{array}{l}2.83-10.32 \\
(6.325)\end{array}$ & $\begin{array}{l}144-187 \\
(167.7)\end{array}$ & $\begin{array}{l}304-584 \\
(485.2)\end{array}$ & $\begin{array}{l}7.5-8.3 \\
(7.775)\end{array}$ & $\begin{array}{l}0.782-0.852 \\
(0.818)\end{array}$ \\
\hline P-2 & $\begin{array}{l}16.25-28 \\
(21.56)\end{array}$ & $\begin{array}{l}42-58.65 \\
45.1\end{array}$ & $\begin{array}{l}4.08-15.18 \\
(8.56)\end{array}$ & $\begin{array}{l}148-188.68 \\
(163.885)\end{array}$ & $\begin{array}{l}344-566 \\
(464)\end{array}$ & $\begin{array}{l}7.8-8.4 \\
(8.07)\end{array}$ & $\begin{array}{l}0.705-0.859 \\
(0.760)\end{array}$ \\
\hline P-3 & $\begin{array}{l}15-26.5 \\
(20.88)\end{array}$ & $\begin{array}{l}38-70 \\
58.32\end{array}$ & $\begin{array}{l}4.06-12.8 \\
(8.575)\end{array}$ & $\begin{array}{l}126-169.93 \\
(146.19)\end{array}$ & $\begin{array}{l}312-532 \\
(449.22)\end{array}$ & $\begin{array}{l}7.7-8.5 \\
(8.1)\end{array}$ & $\begin{array}{l}0.687-0.800 \\
(0.730)\end{array}$ \\
\hline P-4 & $\begin{array}{l}16-27 \\
(21.25)\end{array}$ & $\begin{array}{l}36.5-60.1 \\
51.22\end{array}$ & $\begin{array}{l}5.64-12.15 \\
(8.695)\end{array}$ & $\begin{array}{l}138-172.67 \\
(149.94)\end{array}$ & $\begin{array}{l}336-527 \\
(438.24)\end{array}$ & $\begin{array}{l}7.7-8.6 \\
(8.225)\end{array}$ & $\begin{array}{l}0.661-0.849 \\
(0.726)\end{array}$ \\
\hline
\end{tabular}

Table.3 Growth parameter of study pond

\begin{tabular}{|l|l|l|l|}
\hline Trial & Initial wt of fish(gm) & Final wt of fish $\mathbf{( G m )}$ & $\begin{array}{l}\text { Growth increment }(\mathbf{g m}) \\
\mathbf{1 2 3} \text { days culture period }\end{array}$ \\
\hline $\mathbf{P - 1}$ & 3.0 & 22.25 & 0.182 \\
\hline $\mathbf{P - 2}$ & 3.0 & 90.15 & 0.733 \\
\hline $\mathbf{P - 3}$ & 3.0 & 34.35 & 0.279 \\
\hline $\mathbf{P}-4$ & 3.0 & 44.20 & 0.359 \\
\hline
\end{tabular}



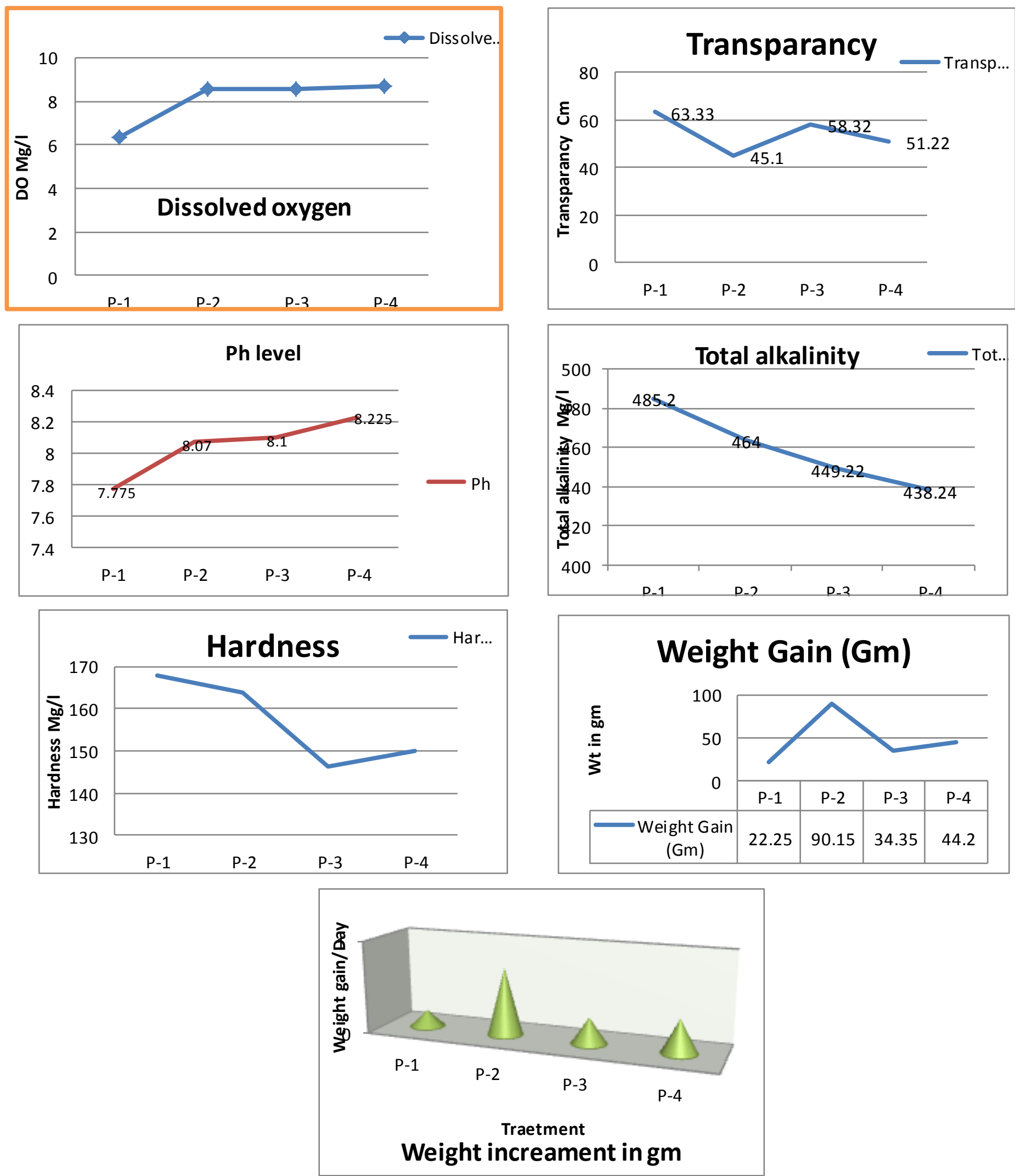
Since long times, animal manures are exploited in fish ponds as a source of soluble phosphorus, nitrogen and carbon to maximize the algal growth and natural food production (Njoku, 1997). Animal manure is often used in semi-intensive systems to improve the primary production of the ponds and fish growth (Nwachukwu, 1997). Manure input and fish yield are directly related with each other (Diana and Lin, 1998; Ansa and Jiya, 2002). Cirrhinus cirrhosus and Cyprinus carpio showed maximum growth in manured ponds than control ponds (Dhawan and Kaur, $2002 \mathrm{a} ; 2002 \mathrm{~b}$ ). Cow dung is found to be an effective source of organic fertilization, which positively influences the growth performance of major carps in respect of fish production (Kanwal et al., 2003). High doses of cow dung and poultry manuringis found to reduce the value of dissolved oxygen (DO), while optimum dose i-e $0.26 \mathrm{kgm}-3$ maintain the better water quality and abundance of planktonic biomass, which improves the growth of carps species (Jha et al., 2004). Ponds manured with cattle dung show higher production by encouraging plankton metabolism (Terziyski et al., 2007). Organic manuring proves to benefit the farmer economically as it serves to reduce $50 \%$ cost of inorganic fertilizer and supplementary feed (Yadava and Garg, 1992).

Summery and conclusion of the study are as follows:

Water quality includes all physical, chemical and biological factors that influence the beneficial use of water. There are many water quality variables in pond fish culture. All other things being equal, a pond with good water quality will produce more and healthier fish than a pond with poor quality. Water quality within an aquaculture pond is continuously changing depending on certain conditions.
The aquaculture pond integrated with pig waste was analyzed in the present study. Study shows that the all physico - chemical properties of pond water were, with in the favorable range. The prime objectives of the study were to measure transparency, Total dissolved solids, ambient temperature, water temperature, and Hydrogen ion concentration. The present study revealed that if the aquaculture pond integrated with washings and left over of 50-55 pigs/ha. Could not disturbed the water quality and it is more economic, ecologically balanced and sustainable system of recycling of organic waste. The farmers of Bundelkhand region should adopt integrated pig-fish farming system to utilize available by products and earn more profit from limited man power and land. It is also suggested that the integrated pond should be under close monitoring. To maintain and manage water quality lime and disinfectants should be applied and replace at list $25 \%$ of water monthly to keep environmental parameter congenial to aquatic animals.

\section{References}

APHA., 1998. Standard Methods for the Examination of Water and Waste Water. 19th Edn., American Public Health Association, Washington, DC., USA., pp: 1360-1371.

Bhatnagar, A. and P. Devi, 2013. Water quality guidelines for the management of pond fish culture. Int. J. Environ. Sci., 3: 1980-2009.

Boyd, C.E., 1990. Water Quality in Ponds for Aquaculture. 2nd Edn., Alabama Agricultural Experiment Station, Auburn University, Auburn, AL., USA., Pp: 482.

Dhawan and S. Kaur (2002) Pig Dung as Pond Manure: Effect on Water, Pond Productivity and Growth of Carps in Polyculture System in Naga, The ICLARM Quarterly (Vol. 25, No. 1) 
January-March 2002 pp11-14

Diana, J.S. and C.K. Lin, 1998. The effects of fertilization and water management on growth and production of Nile tilapia in deep ponds during the dry season. J. World Aquacult. Soc., 29: 405-413.

Edwards, P. 1980. A review of recycling organic wastes into fish, with emphasis on the tropics. Aquaculture, 21: 261279.

Hepher and Pruginin, 1981. Effect of Different Levels of Cow Dung on Growth Performance of Major Carps

Jha, P., Sarkar, K. and Barat, S. 2004. Effect of different application rates of cowdung and poultry excreta on water quality and growth of ornamental carp, Cyprinus carpio var. koi, in concrete tanks. Turkish Journal of Fisheries and Aquatic Sciences 4(17): 22.

Jhingran, V.G. (1991). Fish and Fisheries of India. Hindustan Publishing Corporation, Delhi, pp. 727.

Jhingran, V.G., 1982. Fish and Fisheries of India. 2nd Edn., Hindustan Publishing Corporation, New Delhi, India, pp: 666.

Kanwal et al., 2003. Effect of Different Levels of Cow Dung on Growth Performance of Major Carps, International Journal of Agriculture \& Biology 15608530/2003/05-2-194-195

Kaur, V.I. and M.D. Ansal, 2010. Efficacy of vermicompost as fish pond manureeffect on water quality and growth of Cyprinus carpio (Linn.). Bioresour. Technol., 101: 6215-6218.

Mandal, B.K., 1976. Studies on the primary productivity and physico-chemical factors of fish ponds at Burdwom, west Bengal (India). Archive Hydrobiologie, 18: 175-182.

Njoku DC. 1997. Effects of different manure levels on fish growth, mortality and yield in a horizontally-integrated fishcum-poultry farming system in Nigeria, Aquaculture Research, 28(9): 651 660. June 2008.

Nwachukwu, V. N. (1997). Proceeding on Tilapia nutrition through substrate enhancement in ponds: a cheap, sustainable, and environmentally friendly feeding method. International Symposium on Tilapia in Aquaculture, Coronado Springs Resort Walt Disney World, Orlando, FL, USA, 1: 50-55.

Osborne, J.A. and R.D. Riddle, 1999. Feeding and growth rates for triploid grass carp as influenced by size and water temperature. J. Freshwater Ecol., 14: 41-45.

Salt,D.E., Blaylock, M., Mumar, P.B., Dushenkov, A.N., Ensley, V., Chet, I., and Raskinl (1995). Phyto remediation: A novel strategy for the removal of toxic metals from environments using plants. Biol. Technol. 13: pp 468.

Schroeder, G.L. 1978. Autotrophic and heterotrophic production of microorganisms in intensively manured fish ponds, and related fish yield. Aquaculture, 14 P. 303-325.

Schroeder, G.L. 1980. Fish farming in manureloaded ponds, Integrated AgricultureAquaculture Farming Systems. Pp. 7386.

Terziyski et al., 2007 Effect of organic fertilizer on plankton primary productivity in fish ponds, aquaculture international 15(3):181-190. January 2007.

Yadava and Garg, 1992, Relative efficacy of different doses of organic fertilizer and supplement feed utilization under intensive fish farming, Bio resource Technology, 42(1): 61-65. December 1992.

\section{How to cite this article:}

Kamla Shankar Shukla, C.M. Tripathi and Aditya Kumar Singh. 2019. Effect of Different Compost as Pond Manure on the Water Quality and Growth of Labeo rohita (ham.). Int.J.Curr.Microbiol.App.Sci. 8(02): 1251-1258. doi: https://doi.org/10.20546/ijcmas.2019.802.146 